\title{
Information system on tuberculosis: data completeness spatial analysis in the state of Paraná, Brazil
}

\author{
Sistema de informação em tuberculose: análise espacial da completude dos dados no \\ estado do Paraná \\ Sistema de información sobre tuberculosis: análisis espacial de la completitud de los datos en \\ el estado de Paraná, Brasil
}

How to cite this article:

Silva MS, Arcoverde MAM, Andrade RLP, Zilly A, Villa TCS, Silva-Sobrinho RA. Information system on tuberculosis: data completeness spatial analysis in the state of Paraná, Brazil. Rev Esc Enferm USP. 2021;55:e20200538. DOI: https://doi.org/10.1590/1980-220X-REEUSP-2020-0538

\section{Marcelle Saldanha da Silva ${ }^{1}$ \\ Marcos Augusto Moraes Arcoverde ${ }^{2}$ \\ Rubia Laine de Paula Andrade ${ }^{3}$ \\ D Adriana Zilly ${ }^{2}$ \\ D Tereza Cristina Scatena Villa ${ }^{3}$ \\ Reinaldo Antonio Silva-Sobrinho ${ }^{2}$}

${ }^{1}$ Universidade Estadual do Oeste do Paraná, Programa de Pós-Graduação em Saúde em Região de Fronteira, Foz do Iguaçu, PR, Brazil.

${ }^{2}$ Universidade Estadual do Oeste do Paraná, Foz do Iguaçu, PR, Brazil.

${ }^{3}$ Universidade de São Paulo, Escola de Enfermagem de Ribeirão Preto, Ribeirão Preto, SP, Brazil.

\begin{abstract}
Objective: To analyze the spatiality of completeness of the Information System on Diseases of Compulsory Declaration of tuberculosis in Paraná state, focusing on the border region. Method: A study composed by the notified cases of the disease treated in Paraná between 2008 and 2017. The variable completeness was classified as excellent ( $<5 \%$ of incompleteness), good ( 5 to $<10 \%)$, regular (10 to $<20 \%)$, poor $(20 \%$ to $50 \%)$, and very poor $(>50 \%)$. Moran global was used for the spatial correlation and local association was analyzed. Logistic regression was employed to assess the spatial association of the variables with the border and, for the significant variables, multiple logistic regression was used. The study abides by the resolution 510/2016 of the National Health Council. Results: There was a "high-high" correlation for education level, 2- and 6-month sputum smear in the Eastern health macroregional and "high-high" correlation in the Northwestern macroregional for 2-month sputum smear and antibiotic sensitivity testing. There was no spatial association with the border. Conclusion: Unsatisfactory completeness was identified in the database and conglomerates, indicating spatial association of incompleteness of some variables, but with no relation with the border. There was no worsening of completeness nor of the case outcomes related to these regions.
\end{abstract}

\section{DESCRIPTORS}

Tuberculosis; Health Information Systems; Public Health Surveillance; Disease Notification; Border Areas; Public Health Nursing. 


\section{INTRODUCTION}

Considered a global emergency by the World Health Organization (WHO) in 1993 and a priority in public policies by the Brazilian Ministry of Health (MS) in 2003, tuberculosis still represents a worldwide challenge to public health ${ }^{(1-2)}$. In Brazil, 73,864 new cases were diagnosed in 2019, which corresponds to a coefficient of 35.0 cases per 100,000 citizens $^{(3)}$. Despite being considered curable in most cases and its full treatment being available for the population through the Unified Health System (SUS - Sistema Único de Saúde), Brazil presented 4,490 deaths per tuberculosis in 2019 , which is equivalent to a mortality rate of 2.2 deaths per 100,000 inhabitants ${ }^{(3)}$.

The Brazilian National Program Against Tuberculosis (PNCT - Programa Nacional de Combate à Tuberculose), anchored on the determinations by the WHO End TB Strategy, has the objective of reducing the incidence coefficient to less than 10 cases per 100,000 citizens and reduce the number of deaths due to tuberculosis in the country in $95 \%$ by $2035^{(2)}$. To achieve the determined goals, it is important to assess the actions carried out during the treatment, as well case outcomes, monitoring the disease's tendencies and subsidizing the elaboration of health public policies through data produced and registered in the Health Information Systems (SIS - Sistema de Informação em Saúde), which should be robust and high-quality ${ }^{(4)}$.

One of the attributes of the quality of data is completeness, which is related to the level of completion of a field of the information system ${ }^{(5)}$. The low completeness hinders the assessment of performed actions and of the epidemiological profile of affected individuals, posing difficulties to decisionmaking and elaboration of disease control policies ${ }^{(5)}$. Such circumstance makes it difficult to define the real epidemiological situation of the disease and the case follow-up, since they may be misinterpreted due to an inappropriate completion of the disease notification instruments/follow-up ${ }^{(6)}$.

In addition, tuberculosis cases follow-up in border region municipalities emerges as a challenge, since this region receives a prominent flow of individuals, as well due to the necessity of joint efforts from neighboring countries in order to fight the disease, aligning their policies and health systems, which frequently diverge $\mathrm{e}^{(7)}$. Due to the flow of individuals, these regions present an increased difficulty for diagnosing the disease, treatment adherence and tracking the communicants by reason of the cultural differences and inconsistencies regarding patients' addresses ${ }^{(7)}$.

In view of the above, this study has the objective of analyzing the spatial distribution of completeness of SINAN data regarding tuberculosis and the situation of case outcomes in the state of Paraná, focusing on the border region, from 2008 to 2017.

\section{METHOD}

\section{Type OF Study}

An ecological study.

\section{Population}

The study population comprised the tuberculosis cases notified by SINAN, whose patients had undergone treatment in the state of Paraná in 2008-2017. The state of Paraná is located in Southern Brazil and covers an area of circa $200,000 \mathrm{~km}^{2}$. Its municipalities are grouped into 4 health macro-regions, subdivided into 22 health regionals ${ }^{(8-9)}$.

\section{Data Collection}

Data collection was conducted in July 2019 after they were provided by the General Coordination of PNCT upon request through the website of the Electronic System of the Information Service to the Citizen (e-SIC - Sistema Eletrônico do Serviço de Informação ao Cidadão), available at: https://esic.cgu.gov.br/sistema/site/index.aspx. Epidemiological and operational variables which enabled comprehending disease tendencies were selected: sociodemographic and behavioral variables (residency zone, education level, race/skin color, receiving government support, immigrants, people living on the streets, people deprived of freedom, alcoholism, smoking, and illicit drugs); clinical variables (AIDS, diabetes, mental disease, other comorbidities, pregnancy, 2-month sputum smear, 6-month sputum smear, thorax x-ray, AST [antibiotic sensitivity testing], directly observed treatment, short-course [DOTS] performed, outcome situation [cure, primary abandonment, secondary abandonment, death due to TB, death due to other causes, scheme change, treatment failure]).

\section{Data Analysis and Treatment}

A chi-squared test of the proportion of incompleteness of each variable was performed through R Program. For the variables with the highest indexes of incompleteness (education level, 2- and 6-month sputum smear, illicit drugs, smoking and AST), proportion maps were developed for the spatial distribution observation, considering the state municipalities as units of analysis, observed as per the health macro-regions. The case outcome variable, which presented excellent completeness, was included into the maps in order to assess the association of its completeness with the border situation.

Completeness was classified as excellent (less than 5\% of incompleteness), good (5-10\%), regular (10 to 20\%), poor (20 to $50 \%$ ) and very poor (over $50 \%)^{(10)}$. With the objective of frustrating the overlapping of incompleteness values in the categories "good" and "regular", the cut-off points were adjusted, stipulating as good (5 to $<10 \%)$ and regular (10 to $<20 \%)^{(11)}$.

Global Moran index (Moran's I) was employed for an analysis of the spatial correlation of these variables and, subsequently, LISA (Local Indicators of Spatial Association) was analyzed. For these statistical tools, GeoDa version 1.6.7 software was used. Moran global index assigns a unique value for the analysis of the spatial association degree of the data set as a whole. Moran local, on the other hand, is used to determine the relation of the unit of analysis with their neighboring areas, providing a value for each of them 
and enabling the identification of association patterns with similar values for the selected indicators ${ }^{(12)}$. Associations of the "high-high" type are characterized by municipalities of high index of incompleteness close to municipalities also with high index. Associations "low-low" refer to municipalities with low proportion of incompleteness close to municipalities also presenting this characteristic. Associations of "low-high" are related to municipalities with low proportion of incompleteness close to high proportion municipalities. Finally, associations of "high-low" type refer to units of analysis with high index of incompleteness close to low indexes units.

In order to assess spatial association regarding the border region, logistic regression was applied to the study's variables and the situation of the municipality in relation to the borderland strip was defined as a dependent variable whereas the incompleteness proportions were established as an independent variable. For variables with a significant Odds Ratio (OR), multiple logistic regression was conducted. For these statistical resources, $\mathrm{R}$ program was used. Logistic regression was also employed for the assessment of the relation of border with case outcomes.
The significance level for the analyses was $p<0.05$ and cartographical items were developed through QGIS version 3.4.4. software.

The employed understanding of border defines this as a space of demarcation of the limits of a territory; the Brazilian borderland strip is composed of municipalities whose territories are partially or totally contained in a $150-\mathrm{km}$-wide internal area, parallel to the international limit ${ }^{(13-14)}$.

\section{Ethical Aspects}

This research is in accordance with the determinations of Resolution 466/2021 and 510/2016 of the National Health Council and, due to using public domain data, which cannot enable subject identification, the Research Ethics Committee approval was waived.

\section{RESULTS}

The study population amounted to 23,852 cases diagnosed in the state of Paraná in the period of 2008 to 2017. In the completeness proportion analysis of the variables in the studied municipalities, the sociodemographic and behavioral

Table 1 - Proportion (\%) of the completeness classification as per variable in the municipalities of the state of Paraná - Paraná, Brazil, 2008-2017.

\begin{tabular}{|c|c|c|c|c|c|c|c|c|}
\hline Variable & Excellent & Good & Regular & Poor & VP* & $\mathbf{W R}^{* *}$ & Total & $p$ value \\
\hline \multicolumn{9}{|c|}{ Sociodemographic and behavioral } \\
\hline Residency zone & 85.46 & 7.77 & 4.26 & 1.75 & 0.50 & 0.25 & 100 & $<0.001$ \\
\hline Education level & 20.55 & 9.27 & 25.56 & 38.60 & 5.76 & 0.25 & 100 & $<0.001$ \\
\hline Race/skin color & 91.73 & 4.26 & 3.26 & 0.50 & 0.00 & 0.25 & 100 & $<0.001$ \\
\hline $\begin{array}{c}\text { Receiving } \\
\text { government support }\end{array}$ & 57.14 & 5.01 & 7.02 & 3.51 & 3.51 & 13.78 & 100 & $<0.001$ \\
\hline Immigrants & 75.82 & 2.02 & 2.77 & 4.53 & 1.01 & 13.85 & 100 & $<0.001$ \\
\hline $\begin{array}{l}\text { People living on the } \\
\text { streets }\end{array}$ & 75.94 & 1.75 & 2.51 & 4.76 & 1.25 & 13.78 & 100 & $<0.001$ \\
\hline $\begin{array}{l}\text { People deprived of } \\
\text { freedom }\end{array}$ & 75.44 & 2.51 & 2.76 & 4.76 & 0.75 & 13.78 & 100 & $<0.001$ \\
\hline Alcoholism & 81.20 & 10.53 & 5.76 & 1.75 & 0.50 & 0.25 & 100 & $<0.001$ \\
\hline Smoking & 3.77 & 0.75 & 1.00 & 17.29 & 76.94 & 0.25 & 100 & $<0.001$ \\
\hline Illicit drugs & 4.51 & 0.00 & 1.00 & 16.79 & 77.44 & 0.25 & 100 & $<0.001$ \\
\hline \multicolumn{9}{|l|}{ Clinical } \\
\hline Aids & 64.41 & 14.79 & 11.03 & 9.02 & 0.50 & 0.25 & 100 & $<0.001$ \\
\hline Diabetes & 81.20 & 10.53 & 5.01 & 2.26 & 0.75 & 0.25 & 100 & $<0.001$ \\
\hline Mental disease & 82.71 & 8.27 & 5.51 & 2.51 & 0.75 & 0.25 & 100 & $<0.001$ \\
\hline Other comorbidities & 56.89 & 14.04 & 16.79 & 10.28 & 1.75 & 0.25 & 100 & $<0.001$ \\
\hline Pregnancy & 97.49 & 0.75 & 0.75 & 0.75 & 0.00 & 0.25 & 100 & $<0.001$ \\
\hline $\begin{array}{l}\text { 2-month sputum } \\
\text { smear }\end{array}$ & 31.08 & 15.29 & 22.06 & 25.81 & 5.51 & 0.25 & 100 & $<0.001$ \\
\hline $\begin{array}{l}\text { 6-month sputum } \\
\text { smear }\end{array}$ & 20.55 & 8.02 & 22.81 & 41.60 & 6.77 & 0.25 & 100 & $<0.001$ \\
\hline Thorax x-ray & 93.73 & 4.26 & 1.25 & 0.50 & 0.00 & 0.25 & 100 & $<0.001$ \\
\hline AST*** & 7.52 & 0.00 & 0.75 & 18.80 & 59.15 & 13.78 & 100 & $<0.001$ \\
\hline DOTS performed $* * * *$ & 80.20 & 8.02 & 5.26 & 6.02 & 0.25 & 0.25 & 100 & $<0.001$ \\
\hline Closing situation & 88.72 & 4.01 & 3.51 & 3.26 & 0.25 & 0.25 & 100 & $<0.001$ \\
\hline
\end{tabular}

*VP: Very poor; **WR: Without record; ${ }^{* * * A S T: ~ A n t i b i o t i c ~ S e n s i t i v i t y ~ T e s t i n g ; ~}{ }^{* * *}$ DOTS: directly observed treatment, short-course. 
groups presented the highest percentages of very poor completeness for the variables smoking (76.94\%) and illicit drugs (77.44\%) and higher percentage of poor completeness for education level (38.60\%). The variables race/skin color, zone and alcoholism expressed the highest percentages of excellent completeness in the group, with, respectively, 91.73\%, $85.46 \%$, and $81.20 \%$. The clinical variables exposed a high proportion of very poor completeness for AST (59.15\%) and a high percentage of poor completeness for 2-month sputum smear (25.81\%) and 6-month sputum smear (41.60\%). In this group, the highest percentages of excellent completeness were presented by the variables pregnant (97.49\%), outcome situation (88.72\%), and mental disease (82.71\%) (Table 1).

The spatial distribution of variables which presented the highest indexes of incompleteness included a conglomerate of municipalities in the Eastern health macroregional with poor completeness for the variables education level and 2 - and 6-month sputum smear. For the latter, a conglomerate of municipalities with poor completeness in the
Northwestern macroregional was also verified. Illicit drugs, smoking and AST variables presented a sparse distribution of very poor completeness in the state (Figure 1).

In the local spatial autocorrelation analysis, a similar proportion of high-high correlation is emphasized in the Eastern macroregional for the variables education level, 2- and 6-month sputum smear and outcome situation. The variables 2 -month sputum smear and sensitivity test presented a similar proportion of high-high type in the Northwestern macroregional (Figure 2).

The logistic regression performed with all the variables indicated an association of the borderland strip with higher proportion of incompleteness of the variables AIDS, alcoholism, diabetes, mental disease, illicit drugs and other aggravations (Table 2). However, after the multivariate analysis, the previously observed association had dissipated, suggesting no association of these variables with the border situation (Table 3). The outcome situation of tuberculosis cases in

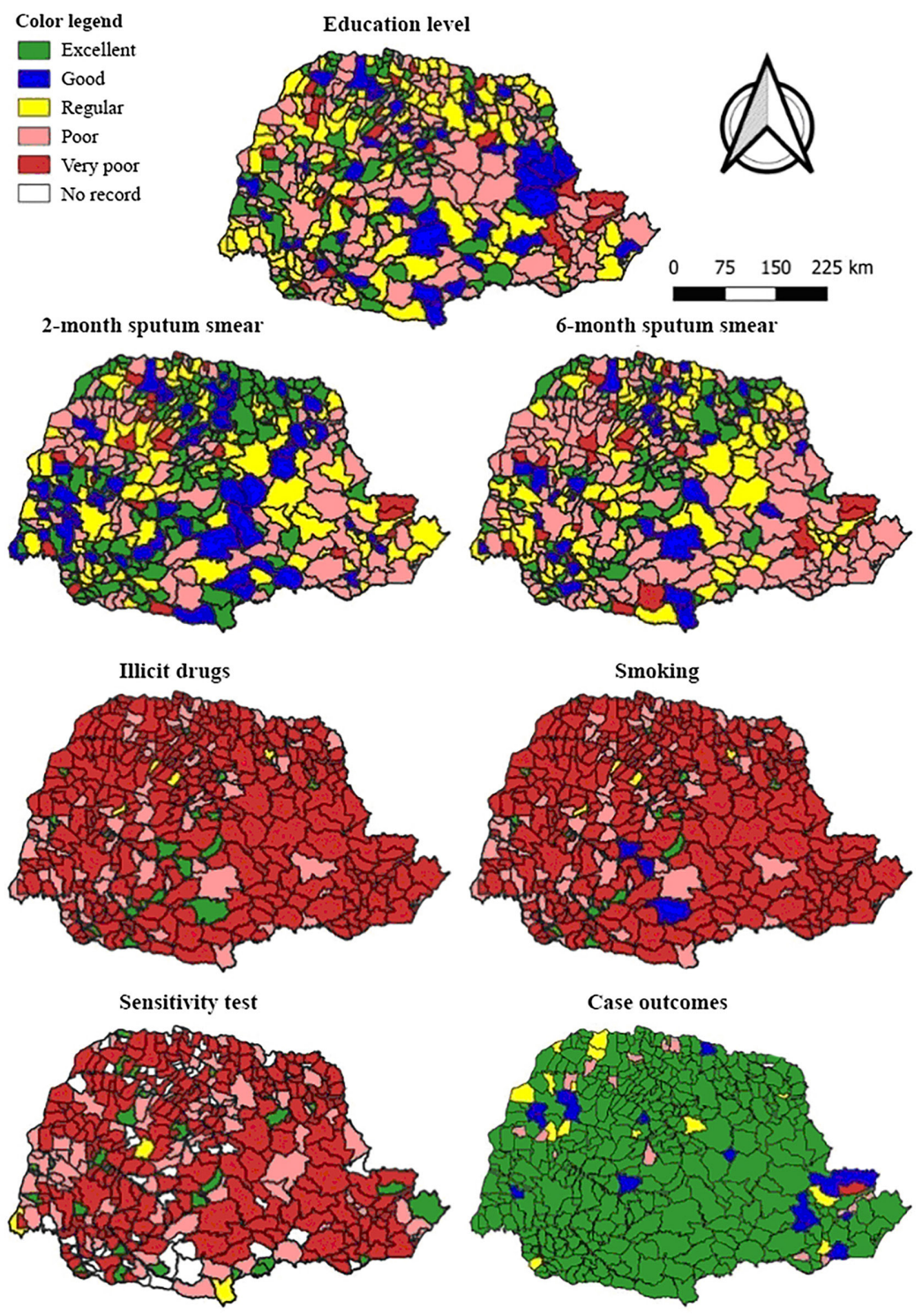

Figure 1 - Spatial distribution of completeness of the variables with the highest proportions of unsatisfactory completeness in the state and outcome situation. 

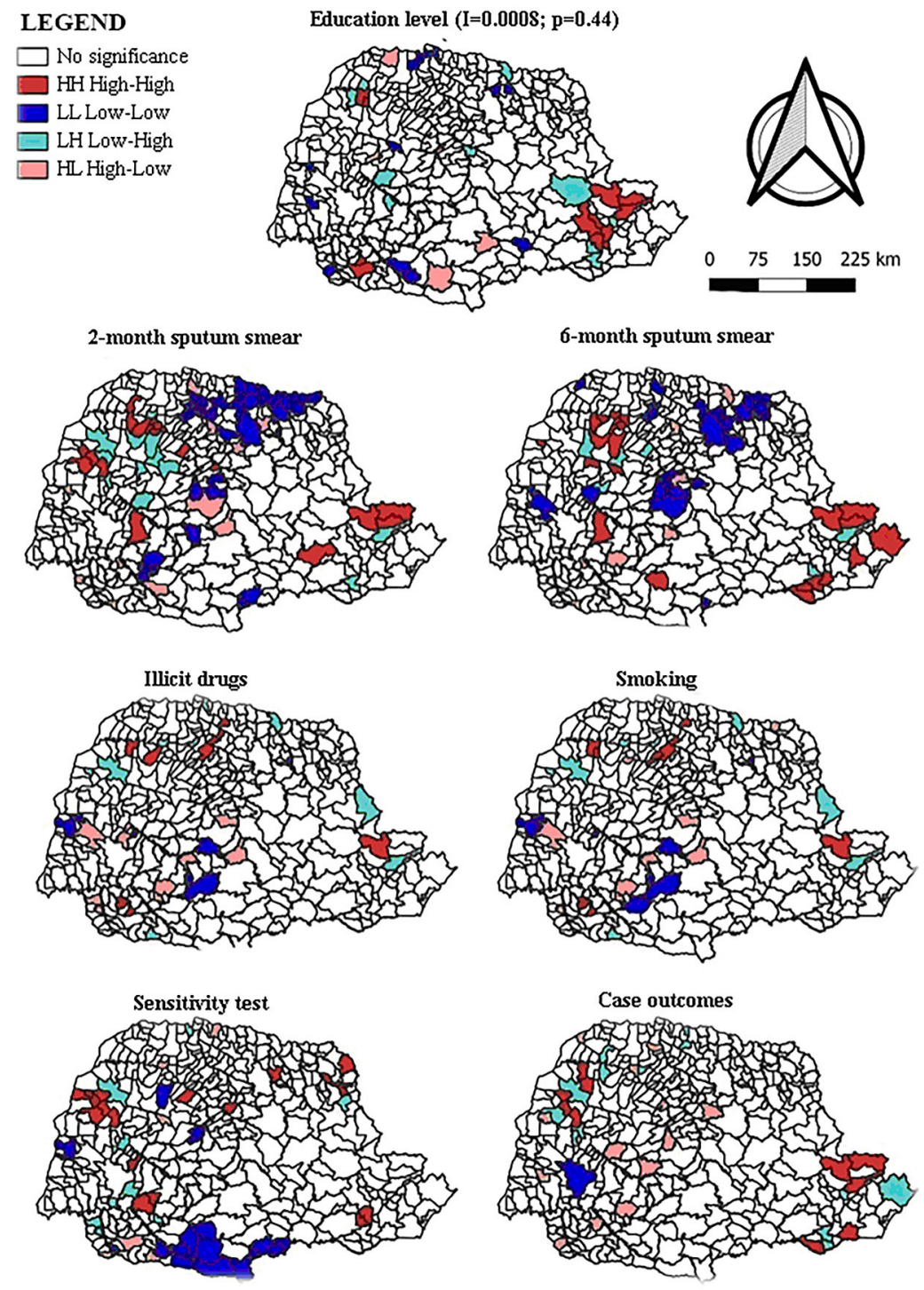

Figure 2 - Local spatial correlation of completeness of the variables with the highest proportions of unsatisfactory completeness in the state and outcome situation.

the state also presented no association with the borderland strip (Table 2).

\section{DISCUSSION}

As an attribute of data quality, completeness is characterized as the level of completion of a certain field in the health information system ${ }^{(5)}$. The more complex and accurate the available data, the higher their utility in understanding the health-disease process; in monitoring demographic, spatial and temporal tendencies of the disease; in decision-making and implementation of strategies and public policies for fighting the disease and in assessing performed actions ${ }^{(4,15)}$.

The municipalities of the state of Paraná presented a high index of excellent completeness for zone, race/color, and alcoholism in the sociodemographic and behavioral variables. The satisfactory completeness of these variables is important, as they are considered predictors for treatment abandonment and negative outcomes due to their relationship with low socioeconomic status and/or difficulties in accessing health services $^{(16)}$. Alcoholism is also related with weaker adherence to the treatment, longer time for negative results of sputum smear and greater risk for medicine toxicity ${ }^{(17)}$.

In this group, the variables which presented the highest indexes of unsatisfactory completeness in the municipalities of the state were smoking, illicit drugs and education level. Knowing the smoking status of the patient diagnosed with pulmonary tuberculosis is important, since, in addition to favoring the infection by the tuberculosis bacillus, smoking is associated with weaker treatment adherence, increasing the risk of disease mortality ${ }^{(18)}$. A study ${ }^{(19)}$ indicated association of smoking with a delay in the conversion of the sputum culture at the end of the second month of treatment and higher chances of unfavorable outcomes.

Similarly to smoking, the use of illicit drugs hinders treatment success. An instable lifestyle, low motivation for self-care ${ }^{(20)}$, the fear of stigma which characterizes illicit drug users and the fragile social support due to a more aggressive behavioral pattern, justified by chemical dependency, 
Table 2 - Logistic regression for the analysis of the association between borderland strip situation and the proportion of incompleteness of variables and cases outcomes - Paraná, Brazil, 2008-2017.

\begin{tabular}{|c|c|c|}
\hline Variables & & OR $(95 \% \mathrm{CI})$ \\
\hline \multirow{10}{*}{$\begin{array}{c}\text { Proportion of incompleteness of } \\
\text { sociodemographic and behavioral } \\
\text { variables }\end{array}$} & Residency zone & $1.01(0.99-1.06)$ \\
\hline & Education level & $1.00(0.99-1.01)$ \\
\hline & Race/skin color & $1.03(0.97-1.13)$ \\
\hline & Receiving government support & $1.00(0.99-1.01)$ \\
\hline & Immigrants & $0.99(0.97-1.01)$ \\
\hline & People living on the streets & $0.99(0.98-1.01)$ \\
\hline & People deprived of freedom & $0.99(0.97-1.01)$ \\
\hline & Alcoholism & $1.06(1.01-1.13)^{*}$ \\
\hline & Smoking & $1.01(0.99-1.01)$ \\
\hline & Illicit drugs & $1.01(1.00-1.02)^{*}$ \\
\hline \multirow{11}{*}{$\begin{array}{c}\text { Proportion of incompleteness of } \\
\text { clinical variables }\end{array}$} & Aids & $1.02(1.00-1.05)^{*}$ \\
\hline & Diabetes & $1.06(1.02-1.12)^{*}$ \\
\hline & Mental disease & $1.06(1.01-1.12)^{*}$ \\
\hline & Other comorbidities & $1.02(1.00-1.03)^{*}$ \\
\hline & Pregnant & $0.96(0.88-1.03)$ \\
\hline & 2-month sputum smear & $0.99(0.98-1.01)$ \\
\hline & 6-month sputum smear & $0.99(0.98-1.00)$ \\
\hline & Thorax x-ray & $1.03(0.97-1.13)$ \\
\hline & AST & $1.00(0.99-1.01)$ \\
\hline & DOTS performed & $1.00(0.98-1.03)$ \\
\hline & Closing situation & $1.00(0.98-1.04)$ \\
\hline \multirow{7}{*}{ Cases outcomes } & Cure & $0.99(0.98-1.00)$ \\
\hline & Primary abandonment & $0.86(0.46-1.46)$ \\
\hline & Secondary abandonment & $1.01(0.98-1.04)$ \\
\hline & Death due to TB & $1.01(0.99-1.04)$ \\
\hline & Death due to other causes & $1.01(0.99-1.03)$ \\
\hline & Scheme change & $1.01(0.88-1.20)$ \\
\hline & Treatment failure & 1.89 (NA) \\
\hline
\end{tabular}

OR: Odds ratio; Cl 95\% Confidence interval 95\%; DOTS: directly observed treatment, short-course; AST: Antibiotic Sensitivity Testing; NA: no possibility of statistical calculation.

*Variables which presented significant confidence interval.

Table 3 - Multivariate analysis of the association of proportion of incompleteness of the variables and border situation - Paraná, Brazil, 2008-2017.

\begin{tabular}{ccc}
\hline Variables & & OR $(\mathrm{CI}$ 95\%) \\
\hline & AIDS & $1.01(0.98-1.04)$ \\
Alcoholism & $1.03(0.94-1.11)$ \\
$\begin{array}{c}\text { Variables which } \\
\text { conented a significant } \\
\text { logistic regression }\end{array}$ & Diabetes & $1.02(0.97-1.12)$ \\
& Mental disease & $1.01(0.96-1.11)$ \\
& Illicit drugs & $1.00(0.99-1.01)$ \\
& Other & $1.00(0.99-1.02)$ \\
\hline
\end{tabular}

constitute factors which hinder treatment adherence ${ }^{(17)}$. Chemical dependency is also associated to an increased time in the search of health services from the onset of symptoms, which contributes to the delay in the diagnosis and the maintenance of the disease transmission chain ${ }^{(21)}$.
Regarding education level, studies emphasize its relationship with the delay in the diagnosis, treatment abandonment, and other negative outcomes ${ }^{(16,22)}$, as low education levels may interfere in the understanding of the severity of the disease and treatment, contributing to therapy interruption, the development of resistant strains and the maintenance of the disease transmission chain ${ }^{(23)}$.

Thus, the importance of registering the socioeconomic and behavioral variables group during notification of individuals diagnosed with tuberculosis enables the identification of those who have higher chances of treatment abandonment and other negative outcomes, whose need for greater attention from the health service during treatment is noteworthy ${ }^{(17,23)}$.

In the clinical variables group, the high index of satisfactory completeness for the variable "pregnant" may be related to its classification as an obligatory field to be filled out, and whose absence prevents notification insertion into the 
information system ${ }^{(24)}$. The high index of satisfactory completeness for the mental health variable is important due to its affinity with greater risk of treatment abandonment and other negative outcomes, which is also observed for other chronic diseases, such as diabetes and HIV/AIDS ${ }^{(17,21)}$.

The mandatory completion of the outcome situation variable enables the visualization of case outcomes through the health information system and enables the development of strategies which aim at reducing the percentage of negative outcomes and assessing the impact of the adopted measures to contain disease progression ${ }^{(2)}$.

The high index of poor completeness presented by the municipalities in the state of Paraná for the 6-month sputum smear may indicate the substitution of this exam by the thorax $x$-ray due to difficulty in expectorating ${ }^{(2)}$, or even that the follow-up is not being properly conducted to the end of the treatment or that it is not being registered ${ }^{(25)}$.

Follow-up of tuberculosis cases is characterized as an effective measure to contain disease aggravation. Among follow-up measures, 2-, 4- and 6-month sputum smear enables the identification of cases which evolve with therapeutic resistance and/or poor treatment adherence, enabling a timely intervention by health professionals ${ }^{(26)}$.

Universal offering of AST is a pilar component of the "prevention and comprehensive and patient-centered care" of the National Plan for the End of Tuberculosis and aims at an early detection of cases of resistant tuberculosis ${ }^{(2,27)}$. The high index of poor completeness for this variable is worrying, since the poor offering of AST contributes to the delay in diagnosing the cases which evolve with resistance, for the continuity of ineffective treatment scheme and for the maintenance of the transmissibility of this type of $\operatorname{strain}^{(27)}$.

For the variables education level and 2- and 6-month sputum smear, there was a significant area of municipalities with poor completeness in the territory which covers the Eastern health macro-region. Amongst the state health macro-regions, the Eastern one presents the greater territorial extension, being composed of the regions of Curitiba, Irati, Ponta Grossa, Paranaguá, Guarapuava, Telêmaco Borba, and União da Vitória ${ }^{(10)}$, comprising the state's coastal portion and the limits between the states of São Paulo and Santa Catarina, in addition to the port region.

As this is a region with high populational density, with two of the most populated municipalities in the state ${ }^{(28)}$, and high mobility due to the coastal region, port, and limits with the state of São Paulo, it is possible to infer that the conglomerate of municipalities with unsatisfactory completeness in this region may be related to individuals who receive the diagnosis in this region and then return to their location. A high-high positive correlation is perceived in municipalities of state limits for 2- and 6-month sputum smear and outcome situation, indicating no register of follow-up, nor of case outcomes.

A significant area of the macroregional Northwestern with unsatisfactory completeness for 6-month sputum smear is noted. This macroregional is composed by the regionals of Campo Mourão, Cianorte, Maringá, Paranavaí and Umuarama, with states limits with Mato Grosso do Sul and São Paulo ${ }^{(9)}$. A high-high correlation for the variables 2-month sputum smear and AST in small municipalities close to the state limit with Mato Grosso do Sul was noticed, which enables to infer that they may be under the influence of this characteristic; however, no studies on the situation of tuberculosis in municipalities in state limits were found.

Variables such as illicit drugs, smoking, and AST presented inadequate completeness proportion sparse for the state. The low completeness of the found variables may be related to the low importance attributed by the health professionals to the notification/data collection procedure for information production $^{(29)}$, low motivation among the professionals or lack of time, prioritizing other activities over notification, which is frequently conceived simply as a bureaucratic activity ${ }^{(30)}$. It is also possible to relate the low completeness with the way this information returns to health professionals, as the visualization of the data applicability enables recognizing the importance of filling up the variables into the health information system and the self-reflection related to the quality of their performance ${ }^{(29)}$.

The multivariate analysis pointed to no spatial relation between the incompleteness of variables with the border region. The intense level of migration and flow of persons, characteristic of these regions, collaborate to disease dissemination and a difficulty in treatment adherence ${ }^{(7)}$; however, this does not seem to be a hindrance to the completeness of the information system.

The possible limitations of this study are related to the use of secondary data, which are susceptible to record inaccuracy and possible underreporting. Nonetheless, the findings contribute to the discussion on the importance of the quality of registers in health information systems, indicating also which regions of the state presented low completeness for the analyzed variables, enabling the development of actions which aim at strengthening the data register into SINAN-TB and the follow-up of tuberculosis cases by health professionals. These interventions are pertinent for the outcome situation of the disease and the maintenance of a trustworthy database, which enables the identification of the epidemiological profile of individuals affected by tuberculosis and facilitates its use as a tool in the assessment of conducted actions for disease control and planning public health policies.

\section{CONCLUSION}

During this study, variables with unsatisfactory completeness in the database of SINAN-TB in the state of Paraná were identified, as well as conglomerates indicating spatial association of the incompleteness of education level,2- and 6-month sputum smear, AST, and outcome situation, but with no relation with the border region.

Even though border regions present characteristics which hinder the diagnosis and follow-up of tuberculosis cases, no worsening of the completeness of variables and of the outcome situation of cases related to these areas was verified.

The failures in the registers of SINAN-TB entail uncertainties regarding the execution of health actions in relation to tuberculosis, i.e., whether they are being 
conducted and not registered, or if, in fact, they are not performed whatsoever. Knowing the regions of the state which present the conglomerates of municipalities with large proportions of unsatisfactory completeness and identifying health macro-regions with positive spatial correlation related to incompleteness enables directing strategies which aim at emphasizing to health professionals the importance of registering the conducts regarding the disease. More than just a bureaucratic task, the careful and complete data completion helps in obtaining information for planning, implementing, and assessing health actions which aim at fighting disease dissemination.

\section{RESUMO}

Objetivo: Analisar espacialmente a completude do Sistema de Informações de Agravos de Notificação referentes à tuberculose no Paraná com foco na região de fronteira. Método: Estudo composto por casos notificados da doença tratados no Paraná entre $2008-2017$. A completude das variáveis classificou-se em excelente ( $<5 \%$ de incompletude), boa (5 a <10\%), regular (10 a <20\%), ruim (20 a 50\%) e muito ruim (>50\%). Utilizou-se Moran global para correlação espacial e analisou-se associação local. Utilizou-se regressão logística para avaliar associação espacial das variáveis com a fronteira e, para as variáveis significativas, realizou-se regressão logística múltipla. O estudo atende à resolução 510/2016 do Conselho Nacional de Saúde. Resultados: Houve correlação "alto-alto" para escolaridade, baciloscopia de $2^{\circ}$ e $6^{\circ}$ mês na macrorregional Leste de saúde e correlação "alto-alto" na macrorregional Noroeste para baciloscopia de $2^{\circ}$ mês e teste de sensibilidade aos antimicrobianos. Não houve associação espacial com a fronteira. Conclusão: Identificou-se completude insatisfatória no banco de dados e conglomerados, indicando associação espacial da incompletude de algumas variáveis, porém, sem relação com a fronteira. Não houve piora da completude ou do encerramento dos casos relacionado a essas regiões.

\section{DESCRITORES}

Tuberculose; Sistemas de Informação em Saúde; Vigilância em Saúde Pública; Notificação de Doenças; Áreas de Fronteira; Enfermagem em Saúde Pública.

\section{RESUMEN}

Objetivo: Analizar espacialmente la completitud del Sistema de Información de Enfermedades Notificables relacionadas con la tuberculosis en el estado de Paraná, con foco en la región fronteriza. Método: Estudio compuesto por casos notificados de la enfermedad tratados en Paraná entre 2008-2017. La integridad de las variables se clasificó como excelente ( $<5 \%$ de incompletitud), buena (5 a $<10 \%)$, regular (10 a <20\%), mala (20 a 50\%) y muy mala (>50\%). Se utilizó Moran global para la correlación espacial y se analizó la asociación local. Se utilizó regresión logística para evaluar la asociación espacial de las variables con la frontera y, para las variables significativas, se realizó una regresión logística múltiple. El estudio cumple con la Resolución 510/2016 del Consejo Nacional de Salud. Resultados: Hubo una correlación "alta-alta" para educación, baciloscopia de $2^{\circ}$ y $6^{\circ}$ mes en la macrorregión de salud Este y correlación "alta-alta" en la macrorregión Noroeste para baciloscopia de $2^{\circ}$ mes y prueba de sensibilidad a los antibióticos. No hubo asociación espacial con la frontera. Conclusión: Se identificó una completitud insatisfactoria en la base de datos y los conglomerados, lo que indica una asociación espacial de incompletitud en algunas variables, sin embargo, no relacionadas con la frontera. No hubo empeoramiento de la completitud o conclusión de los casos relacionados con estas regiones.

\section{DESCRIPTORES}

Tuberculosisi; Sistemas de Informação en Salud; Vigilancia en Salud Pública; Notificación de Enfermedades; Áreas Fronterizas; Enfermería en Salud Pública.

\section{REFERENCES}

1. Word Health Organization. The end TB strategy [Internet]. Geneva: WHO; 2015 [cited 2020 June 14]. Available from: https://www.who. int/tb/End_TB_brochure.pdf?ua=1

2. Brasil. Ministério da Saúde; Secretaria de Vigilância em Saúde. Manual de recomendações para o controle da tuberculose no Brasil. Brasília; 2019.

3. Boletim Epidemiológico Tuberculose. Brasília: Ministério da Saúde, Secretaria de Vigilância em Saúde [Internet]. 2020 [cited 2020 jun. 14];(n.esp.). Available from: https://www.gov.br/saude/pt-br/centrais-de-conteudo/boletim-tuberculose-2020-marcas-1-pdf

4. Mlotshwa M, Smit S, Williams S, Reddy C, Medina-Marino A. Evaluating the electronic tuberculosis register surveillance system in Eden District, Western Cape, South Africa, 2015. Glob Health Action. 2017;10(1):1360560. https://doi.org/10.1080/16549716.2017.1360560

5. Marques CA, Siqueira MM, Portugal FB. Avaliação da não completude das informações compulsória de dengue registradas por município de pequeno porte no Brasil. Ciênc Saúde Coletiva. 2020;25(3):891-900. https://doi.org/10.1590/1413-81232020253.16162018

6. Pradana AR, Purnami CT, Mawarni A. Literature review: data quality assessment methods of tuberculosis recording and reporting electronically. Int J Health Educ Soc. 2020;3(7):1-15. https://doi.org/10.1234/ijhes.v3i7.97

7. Souza DCS, Oliveira KS, Andrade RLP, Scatena LM, Silva-Sobrinho RA. Aspects related to the outcomes of the treatment, in international borders, of cases of tuberculosis as associated to comorbidities. Rev Gaúcha Enferm. 2019;40:e20190050. http://dx.doi.org/10.1590/19831447.2019.20190050

8. Instituto Brasileiro de Geografia e Estatística. Paraná: panorama geral [Internet]. Rio de Janeiro: IBGE; 2020 [cited 2020 jan. 2]. Available from: https://cidades.ibge.gov.br/brasil/pr/pesquisa/23/27652?detalhes=true

9. Paraná. Secretaria da Saúde do Estado. Regionais de Saúde [Internet]. Curitiba; 2020 [cited 2020 jan. 6]. Available from: https://www. saude.pr.gov.br/Pagina/Regionais-de-Saude

10. Romero DE, Cunha CB. Avaliação da qualidade das variáveis epidemiológicas e demográficas do Sistema de Informações sobre Nascidos Vivos, 2002. Cad Saúde Pública. 2007;23(3):701-14. https://doi.org/10.1590/S0102-311X2007000300028 
11. Lino RRG, Fonseca SC, Kale PL, Pinheiro RS, Coeli CM. Trend of incompleteness of vital statistics in the neonatal period, State of Rio de Janeiro, Brazil, 1999-2014. Epidemiol Serv Saúde. 2019;29(2):e2018131. http://dx.doi.org/10.5123/S1679-49742019000200014

12. Luzardo AJR, Castañeda Filho RM, Rubim IB. Análise espacial exploratória com o emprego do índice de Moran. GEOgraphia. 2017;19(40). https://doi.org/10.22409/GEOgraphia2017.v19i40.a13807

13. Karpinski C, Matiauda DIG. Paisagem e fronteira nas questões territoriais entre Argentina e Brasil (1960-1914). Rev NUPEM. 2017;9(17): 72-85. https://doi.org/10.33871/nupem.v9i17.321

14. Brasil. Lei n. 6.634 de 2 de maio de 1979. Dispõe sobre a faixa de fronteira, altera o decreto-lei $n^{\circ} 1.135$ de 3 de dezembro de 1970 , e dá outras providencias [Internet]. Brasília;1979 [cited 2020 fev. 12]. Available from: http://www.planalto.gov.br/ccivil_03/Leis/L6634.htm

15. Zeng X, Adair T, Wang L, Yin P, Qi J, Liu Y, et al. Measuring the completeness of death registration in 2844 Chinese counties in 2018. BMC Med. 2020;18:176. https://doi.org/10.1186/s12916-020-01632-8

16. Prado TN, Rajan JV, Miranda AE, Dias ES, Cosme LB, Possuelo LG, et al. Clinical and epidemiological characteristics associated with unfavorable tuberculosis treatment outcomes in TB-HIV co-infected patients in Brazil: a hierarchical polytomous analysis. Braz J Infect Dis. 2017;21(2):162-70. http://dx.doi.org/10.1016/j.bjid.2016.11.006

17. Duarte R, Lonroth K, Carvalho C, Lima F, Carvalho ACC, Munoz-Torrico M, et al. Tuberculosis, social determinants and co-morbidities (including HIV). Pneumology. 2018;24(2):115-9. http://dx.doi.org/10.1016/j.rppnen.2017.11.003

18. Khan AH, Sulaiman SAS, Hassali MA, Khan KU, Ming LC, Mateen O, et al. Effect of smoking on treatment outcome among tuberculosis patients in Malaysia: a multicenter study. BMC Public Health. 2020;20:854. https://doi.org/10.1186/s12889-020-08856-6

19. Cailleaux-Cezar M, Loredo C, Silva JRL, Conde MB. Impact of smoking on sputum culture conversion and pulmonary tuberculosis treatment outcomes in Brazil: a retrospective cohort study. J Bras Pneumol. 2018;44(2):99-105. https://doi.org/10.1590/s1806-37562017000000161

20. Sá AMM, Santiago LA, Santos NV, Monteiro NP, Pinto PHA, Lima AM, et al. Causas de abandono do tratamento entre portadores de tuberculose. Rev Soc Bra Clin Med. 2017;15(3):155-60.

21. Silva DR, Munoz-Torrico M, Duarte R, Galvão T, Bonini EH, Arbex FF, et al. Risk factors for tuberculosis: diabetes, smoking, alcohol use, and the use of the other drugs. J Bras Pneumol. 2018;44(2):145-52. http://dx.doi.org/10.1590/s1806-37562017000000443

22. Cardoso MA, Brasil PEAA, Schmaltz CAS, Sant'Anna FM, Rolla VC. Tuberculosis treatment outcomes and factors associated with each of them in a cohort followed up between 2010 and 2014. Biomed Res Int. 2017;2017:3974651. https://doi.org/10.1155/2017/3974651

23. Moreira ASR, Kritski AL, Carvalho ACC. Social determinants of health and catastrophic costs associated with the diagnosis and treatment of tuberculosis. J Bras Pneumol. 2020;45(5):e20200015. https://doi.org/10.36416/1806-3756/e20200015

24. Brasil. Ministério da Saúde; Secretaria de Vigilância em Saúde, Departamento de Vigilância Epidemiológica. Sistemas de Informação de Agravos de Notificação. Normas e Rotinas [Internet]. Brasília; 2006 [cited 2021 fev. 18]. Available from: http://bvsms.saude.gov.br/bvs/ publicacoes/sistema_informacao_agravos_notificacao_sinan.pdf

25. Canto VB, Nedel FB. Completeness of tuberculosis records held on the Notifiable Health Conditions Information System (SINAN) in Santa Catarina, Brazil, 2007-2016. Epidemiol Serv Saúde. 2020;29(3):e2019606. https://doi.org/10.5123/s1679-49742020000300020

26. Lima LM, Harter J, Tomberg JO, Vieira DA, Antunes ML, Cardoso-Gonzales RI. Monitoring and assessment of outcome in cases of tuberculosis in a municipality of Southern Brazil. Rev Gaúcha Enferm. 2016;37(1):e51467. https://doi.org/10.1590/1983-1447.2016.01.51467

27. Savioli MTG, Morrone N, Santoro I. Primary bacillary resistance in multidrug resistance tuberculosis and predictive factors associated with cure at a referral center in São Paulo, Brazil. J Bras Pneumol. 2019;45(2):e20180075. https://doi.org/10.1590/1806-3713/e20180075

28. Instituto Brasileiro de Geografia e Estatística. Sinopse do censo demográfico 2010: Paraná [Internet]. Rio de Janeiro: IBGE; 2010 [cited 2020 jan. 20]. Available from: https://censo2010.ibge.gov.br/sinopse/index.php?dados=0\&uf=41

29. Rocha MS, Bartholomay P, Cavalcante MV, Medeiros FC, Codenotti SB, Pelissari DM, et al. Notifiable Diseases Information System (SINAN): main features of tuberculosis-related notification and data analysis. Epidemiol Serv Saúde. 2020;29(1):e2019017. https://doi. org/10.5123/S1679-49742020000100009

30. Siqueira PC, Maciel ELN, Catão RC, Brioschi AP, Silva TCC, Prado TN. Completeness of yellow fever notification forms in the state of Espírito Santo, Brazil, 2017. Epidemiol Serv Saúde. 2020;29(3):e2019402. http://dx.doi.org/10.5123/s1679-49742020000300014 